\title{
Dangerous Crossings: Gender and Criticism in Arabic Literary Studies
}

\author{
Fedwa Malti-Douglas
}

When the Egyptian writer Naguib Mahfouz was awarded the Nobel Prize for Literature in 1988, it seemed that Arabic literature was at once poised and destined to play an important role in world literature. Visions of Arabic literature in translation flooding the Western reading world danced before the eyes of Arabic specialists, too long consigned to the outer limits of the academy. Places of honor in airport bookshops seemed within easy reach. But, as many specialists of Middle Eastern literature have lamented, this prize has had little effect on the recognition of Arabic literature in the Western literary-critical community. Arabic literature remains foreign, on the far side of a border that few even think about crossing. Taught and read by regional specialists, it is treated essentially as an aid to the practical understanding of a region of the world whose chief exports are oil and terrorism. Recognition of Arabic literature as a significant part of the human cultural heritage and a player in the creation of contemporary world culture is as lacking today as it was a decade ago. Certainly the airport bookstore is as far away as ever!

At the same time, other specialists in the Middle East are actively bemoaning something else; the growth of Western-language translations of feminist women's writings from the Arab world. These are perceived as more dangerous than those of their male compatriots (or even nonfeminist women writers) because more critical. Such works have still not reached the airport bookstores, but their circulation in academic circles has already generated anxiety among specialists in Arabic and Islamic studies.

I write as an Arab and as a woman. My analyses are informed by a variety of critical methodologies. Yet when I cross Arabic literature with gender criticism, trouble emerges. How? Why?

Time was, in the early years of our century, when a writer such as the British scholar R. A. Nicholson could saunter gaily through the field 
of medieval Arabic letters isolating one or another author and comparing him to Western writers. The "him" is intended here: scriptors of the medieval Arabo-Islamic world were generally males. ${ }^{1}$ Thus it was that Ibn Khallikân became the Boswell of the Arabs. ${ }^{2}$ This was one way of domesticating Arabic literature, of denuding it of some of its alterity, of making it seem familiar and undaunting to the Western reader.

These antiquated forms of comparison are now just that-antiquated. But if we were once beleaguered by them, we are now beleaguered by something quite different: objections from many within the field to new critical methodologies, new analytical approaches, as if labor-filled years of philological training produced analytical blinders. The faster the non-Arabic humanities progressed, the more isolated and ingrained the analysis of the Arabic humanities became. Certainly this has been the record of the last half century. The solution: imprison the Arabic text in an ostensibly nonmethodological straitjacket, put an analytical chastity belt on it, protect it. Academic traditionalists in Arabic studies call literary criticism a fad, in the obvious hope that if they close their eyes long enough it will go away. Do these "fads" or "fashions" help us to understand the text? Do they inform the text? These questions are not even addressed. How could they be? To counter theory, you need to use theory.

At the forefront of the battle, and undergoing the most vigorous attack, is gender criticism. Oddly enough, gender unifies political ideologues who seem to disagree on everything but how to write (or rather not to write) Arab feminism. One can oppose feminist work because it is a species of literary criticism. One can oppose it because it is allegedly non-Arab in origin. One can oppose it because it is associated with social movements that threaten entrenched groups in the American academy.

The dilemma of the comparatist Arab feminist is double. Arabic literature, centuries old, needs to enter the canon if that canon is to have any pretense of universality. "Monoculturalism," to use Lillian S. Robinson's highly loaded term, has become increasingly difficult to defend. ${ }^{3}$ I use the term canon here as cultural shorthand. Do we need a fixed, or a slowly evolving, list of "great works?" However one answers this question, there are at any point in time circuits both intellectual

${ }^{1}$ For a discussion of the gendering of Arabic scriptural traditions, see Fedwa MaltiDouglas, Woman's Body, Woman's Word: Gender and Discourse in Arabo-Islamic Writing (Princeton: Princeton University Press, 1991).

'See, for example, R. A. Nicholson, A Literary History of the Arabs (Cambridge: Cambridge University Press, 1969), 452. Nicholson's work was first published in 1907.

'Lillian S. Robinson elucidated this point at a public lecture, "Get a Life," at the University of Texas, Austin, September 5, 1990. I am grateful to her for this reference. 
and physical: books that are read, books that are taught, books that are bought.

The question is: Through what door does Arabic literature enter these circuits, and what is written on its passport? Third world literature, emergent literature, postcolonial literature: these are categories that elicit much positive response. But to sneak Arabic literature through the door as an emergent literature, to take but one example, is to do it a grave injustice. For the nonspecialist Westerner, Arabic literature is an emergent literature because recently discovered. Yet Arabic literature is far older than literature in any modern European language. To treat the more recent products of this self-conscious tradition as emergent or third world or postcolonial literature is to sever the modern Arabic literary product from its textual heritage. This severing is even more violent now that contemporary Arabic authors are playing intertextual games with their own tradition. Interestingly enough, this is taking place across continents, from the Palestinian Emile Habiby to the Egyptian Jamâl al-Ghîtânî and the Tunisian Mahmûd al-Misadî. ${ }^{4}$

The contemporary Arab, even the barely educated one, knows that he or she has a literary heritage, for he or she has lived around the literary and religious classics from an early age. Quotations from the holy book, the Qur'ân, and from the hadith, the reported actions and sayings of the Prophet Muhammad, are broadcast daily on radio and television. The contemporary Arab moviegoer is not surprised to hear verses from a sixth-century Arabic ode recited on the screen. ${ }^{5}$ The sidewalks of Middle Eastern capitals teem with premodern texts, bound editions of the more popular classical works at reasonable prices. Do you have a stomach ailment? Medieval manuals of "Prophetic medicine" are available for your purchase and use. Do you fancy anecdotal literature or homiletics? Here again you will not be disappointed. Or would you prefer erotic manuals from the Middle Ages? You have but to wander the souks of Marrakesh or the West Bank.

That is one problem. A related problem lies precisely in the appeal

\footnotetext{
${ }^{4}$ See, for example, Fedwa Malti-Douglas, "Mahfouz's Dreams," in Naguib Mahfouz: From Regional Fame to Global Recognition, ed. Michael Beard and Adnan Haydar (Syracuse: Syracuse University Press, 1993), 126-43, 183-85. In the case of Egypt, for example, even this model needs to be modified: contemporary novelists and dramatists also exploit Ancient Egyptian materials. See, for example, Fathî Sa fd, al-Fallâh al-Fasîh (Cairo: AlHay'a al-Misriyya al-Amma lil-Kitâb, 1982); Muhammad Mahrân al-Sayyid, Hikâya Min Wâdî al-Milh (Cairo: Mu'assasat Inân lil-Tibâa, 1984); Alî Ahmad Bâkathîr, al-Fallâh alFasîh (Cairo: Maktabat Misr, 1985); Jamâl al-Ghîtânî, "Shakâwâ al-Fallâh al-Fasîh," in ArdArd (Beirut: Dâr al-Masîra, 1980), 123-43; Yûsuf al-Qậd, Shakâwâ al-Misrî al-Fasîh, vol. 1 (Beirut: Dâr al-Masîra, 1981); vol. 2 (Cairo: Dâr al-Mustaqbal al- Arabî, 1983); vol. 3 (Cairo: Dâr al-Mustaqbal al- Arabî, 1985).

${ }^{5}$ See, for example, Yûsuf Shâhîn's very popular film al-Ard (The earth), 1968.
} 
of texts by and on women for the nonspecialist Western audience. It is a vicarious appeal linked to the call of the harem, the exotic, the alien. Yet it is most of ten the supposedly unmediated testimony that attracts the widest audiences-the interview (whether ethnographic or journalistic), the memoir, or indeed any first-person narrative that is deemed (quite naively in effect) to reflect personal or social realities. Or all of these: the anthology of bite-sized morsels. Like a tourist, the reader thinks he or she is getting the authentic, the peek behind the veil. But we know that there are no unmediated texts. Authenticity is a mirage, as unreal as the tourist's search for the nontourist experience. Analyses are less popular. More demanding, they risk disturbing the Westerner's comfortable righteousness as they highlight patriarchal forms not exclusive to the region.

The woman scriptor is a relatively new phenomenon in the AraboIslamic literary tradition. She may be new, but she is not ignorant. Her texts are more often than not informed by the male literary tradition she grew up with. Like her male colleagues, she plays intertextual games, onomastic games, literary-cultural games. She is as deserving of serious study as the male author. To set the Arab woman writer in a category apart is also to sever her from her heritage, in much the same way that Arabic literature is severed when treated as an emergent literature. Yet, studying Arab women's writings in a gender-conscious way is, for some within the field of Middle Eastern studies, increasingly suspect.

October 1992. I travel to the land of colorful trees. Three different settings. The first is a women's studies audience in a big city university; the second, an exclusive seminar in a prestigious Ivy League university; the third, a mixed audience in yet another Ivy League institution. In the first I talk about a prominent Arab feminist's prison memoirs. In the second I talk about a novel by that same feminist. In the third I talk about a prominent woman Islamist. Two Arab female intellectual figures whose politics are radically opposed to each other.

The listeners' responses? From all too many a remarkable convergence of fears. And a remarkable convergence on a single policy: silence. On the one hand, to talk of women is to disempower them-this was said about a leading media personality who is unlikely to be silenced by anything written on this side of the Atlantic. On the other hand, a feminist approach is a threat. By talking about the forbidden, by exposing that which should remain hidden (dare I say behind a veil), am I not exposing Arab society as "pathological"? (I put this word in quotes because it is the very word that surfaced in the discussion.)

The three audiences are peppered with avowed Marxists. Some of 
them belong to the methodologically most conservative wing of Middle Eastern studies. Philology and Marxism make strange bedfellows. Yet they come together when it is time to close one's eyes to gender issues. Scholars whose considerable intellects are paralyzed by a methodological conservatism bordering on inertia can hide behind a fashionable caricature of Marxism and anti-imperialism. Do not class relations take precedence over gender ones? Does a focus on Arab or Muslim women not betray a species of cultural imperialism? These scruples make useful prophylactics, protecting their wearer from potentially disturbing critical and social issues.

One solution to this pervasive gender problem was actually proposed at the Ivy League seminar: a particularly vehement youngish male full professor from a neighboring, and equally Ivy, institution suggested tracking down the guilty publishers to dissuade them from disseminating these Arab feminist texts in translation. No one around the table objected. The strength of his fear apparently blinded this otherwise intelligent colleague to the utter impracticality of his form of censorship. Another form of severing! I wish I could say that this was an isolated case. The only unusual thing about it was its public frankness. Recommendations of silence are commonly delivered in a friendly tone by well-meaning colleagues.

Methodological obscurantism allies itself with the desire to protect the integrity of Arab civilization. Their point of contact: the idea that it is inappropriate to analyze Arab civilization with foreign (read: Western) intellectual tools. But this mode of protecting Arab civilization is alien to that civilization itself. Medieval Arabo-Islamic culture was, in its finest moments, intellectually open, unafraid, self-confident. And the modern Middle East? There is not a single cultural force or figure in the region, down to the most neotraditionalist of Islamic revivalists, whose thought has not been shaped by contact with the West and its ideas. The notion of a modern Arab culture free of Western taint is as mythical as the unmediated testimony, another touristic dream.

The modern critical dialogue about gender becomes embedded, therefore, in discourses of power and control. Who has the right to speak about the Arab world and about Arab women? At a women's panel that took place not so long ago at the national meeting of the Middle East Studies Association, several Arab women suggested that only Arab women had the right to speak about the Arab woman. History has shown that such identity politics lead ultimately to the defense of existing power groups. Besides, this assertion begs the question of what an Arab woman is. Is she the one living in the Arab world and who knows only Arabic? Is she the one living in North Africa and who 
is literate only in French? Is she the one living in Europe or America and writing in Arabic? Is she the one living abroad and writing in French or English?

The discourse of power goes deeper. Does the individual who speaks have the right to discuss issues that place the Arabs in a bad light? And primary here is the question of women. After all, why add insult to injury? If the Arabs already have a bad press (and we know that they do), ${ }^{6}$ are gender critics not aggravating this problem by raising questions that should better remain dormant?

This argument has clear appeal, and it appeals to many. But why is it that other injustices, like those of wealth and poverty or those of political oppression, can be invoked without fear of adding to the bad name of the Arabs? Why are the most searing of social novels (and social novelists) welcomed by some of the very same people who reject the equally leftist radical feminists? Could it be that attacks on capitalism and imperialism do not threaten academics (a salaried class indeed) the way that those on patriarchy do?

This concern to protect suggests that somehow Arabs should be treated as a category apart because they are supposedly unable to hear criticism of their society or of gender issues. This is the height of cultural arrogance; its result is not to protect but to isolate. No number of Nobel Prizes could then make an impact.

${ }^{6}$ For such an exposé, see, for example, Jack G. Shaheen, The TV Arab (Bowling Green, Ohio: Bowling Green State University Popular Press, 1984). 